\title{
Akurasi Nilai Tinggi Matahari antara Perhitungan Daftar Ilmu Pelayaran (DIP) dan Sight Reduction Table (SRT)
}

\author{
Slamet Riyadi ${ }^{1}$, Dwi Antoro ${ }^{2}$, I Made Wahyu S.P ${ }^{3 *}$, Hilda Emeraldo A.A ${ }^{4}$ \\ i_made_wahyu@pip-semarang.ac.id
}

Diterima 23 Juni 2021, direvisi 06 September 2021, diterbitkan 06 Oktober 2021

\begin{abstract}
Abstrak
Penentuan posisi dengan benda angkasa (celestial navigation) merupakan seni menentukan posisi di permukaan bumi berdasarkan pengukuran benda angkasa yang mana telah membimbing para pelaut selama ratusan tahun. Metode penentuan posisi secara astronomi atau navigasi benda angkasa semakin menjadi usang dan jarang digunakan. Faktanya pada zaman sekarang ini, seiring dengan kemajuan teknologi tersebut para pelaut lebih memilih menggunakan alat navigasi elektronik seperti Global Positioning System (GPS). The International Convention on Standard of Training, Certification and Watchkeeping for Seafarers (STCW) amandemen 2010, mewajibkan semua perwira di kapal yang bertanggung jawab atas navigasi untuk bisa menentukan ketinggian benda langit, garis posisi atau Line of Position (LOP) dan posisi kapal. Pada umumnya penetuan posisi navigasi benda angkasa terdapat 2 Metode perhitungan yaitu dengan perhitungan tabel Daftar Ilmu Pelayaran dan Sight Reduction Table. Pada Penelitian ini membahas tentang akurasi penentuan tinggi hitung matahari dengan membandingkan tingkat akurasi 2 metode tersebut. Metode yang digunakan adalah deskriptif komparatif berbasis field research dengan pendekatan kuantitatif Teknik Pengumpulan data dilakukan dengan cara observasi, dokumentasi dan studi pustaka. Tujuan dilakukan penelitian ini adalah untuk menguji tingkat akurasi masing-masing metode perhitungan yaitu perhitungan Daftar Ilmu Pelayaran (DIP) dan Sight Reduction Table (SRT). Hasil yang didapat dalam penelitian ini adalah akurasi perhitungan tinggi hitung metode perhitungan daftar ilmu pelayaran lebih akurat dengan dilakukan pengujian yang selanjutnya dibahas lebih lanjut di dalam penelitian ini
\end{abstract}

Kata kunci: Tinggi Hitung Matahari, Navigasi Benda Angkasa, Daftar Ilmu Pelayaran, Sight Reduction Table

\section{Abstract}

Positioning with celestial bodies (celestial navigation) is the art of determining on the surface of the earth based on measurements of celestial bodies which have guided sailors for hundreds of years. Astronomical positioning methods or celestial body navigation are becoming increasingly obsolete and rarely used. The fact is that today, along with technological advances, seafarers prefer to use electronic navigation tools such as the Global Positioning System (GPS). The the International Convention on Standard of Training, Certification and Watchkeeping for Seafarers (STCW) amended 2010, requires all officers on board responsible for navigation to be able to determine the height of celestial bodies, the Line of Position (LOP) and the position of the ship. In general, there are 2 methods of determining the navigation position of celestial bodies, namely by calculating the Sight Reduction Table and Daftar Ilmu Pelayaran.. This research discusses the accuracy of determining the height of the solar count by comparing the accuracy of the 2 methods. The method used is descriptive comparative based on field research with a quantitative approach. The technique of collecting data was done by means of observation, documentation and literature study. The purpose of this research is to test the accuracy of each calculation method, namely the calculation of the Sailing List (DIP) and the Sight Reduction Table (SRT). The results obtained in this study are the accuracy of altitude calculation method of calculating by Daftar Ilmu Pelayaran is more accurate with testing which is further discussed in this study.

Kata Kunci: Sun Altitude, Celestial Navigation, Daftar Ilmu Pelayaran, Sight Reduction Table 


\section{Pendahuluan}

Pada zaman dahulu para pelaut menentukan posisi kapal dengan observasi benda angkasa maupun benda darat. Salah satu metode navigasi tersebut adalah navigasi angkasa (celestial navigation) yang melibatkan pengukuran angkasa ke garis posisi menggunakan tabel, trigonometri bola dan almanak sehingga dengan cara tersebut mereka berlayar dengan aman dan selamat sampai ke tujuan. Penentuan posisi dengan benda angkasa (celestial navigation) merupakan seni menentukan posisi di permukaan bumi berdasarkan pengukuran benda angkasa yang mana telah membimbing para pelaut selama ratusan tahun [1].

Metode penentuan posisi dengan benda angkasa semakin menjadi jarang digunakan. Sejak tahun 1950-an sistem navigasi elektronik telah mengambil alih navigasi benda angkasa (celestial navigation) yang mampu memberikan pengukuran posisi yang akurat kepada pengguna [2]. Faktanya pada zaman sekarang ini, seiring dengan kemajuan teknologi tersebut para pelaut lebih memilih menggunakan alat navigasi elektronik seperti Global Positioning System (GPS), sehingga mulai meninggalkan metode perhitungan posisi dengan navigasi benda angkasa. Alat-alat navigasi tersebut tidak sepenuhnya sempurna, sinyal yang diterima dari satelit GPS terkadang tidak muncul karena suar matahari (solar flares), badai magnet (magnetic storm) atau alasan lain [3].

Berdasarkan The International Convention on Standard of Training, Certification and Watchkeeping for Seafarers (STCW) amandemen 2010, mewajibkan semua perwira di kapal yang bertanggung jawab atas navigasi untuk bisa menentukan ketinggian benda langit, garis posisi atau Line of Position (LOP) dan posisi kapal. Di sisi lain dari STCW Amandemen 2010 tentang pendidikan dan Pelatihan terkait navigasi angkasa, mendorong penggunaan almanak elektronik dan perangkat lunak penghitungan lainnya [4].

Maka dengan perkembangan teknologi yang sangat signifikan tersebut para pelaut tetap harus menguasai cara perhitungan penentuan posisi navigasi benda angkasa karena merupakan salah satu alternatif metode penentuan posisi yang dapat digunakan ketika mengalami masalah pada sistem navigasi elektronik, kerusakan system kelistrikan kapal hingga blackout akan tetapi pada dewasa ini sangat sulit untuk menemukan seorang perwira di atas kapal yang akrab dengan penggunaan praktis dari sextant dan almanak nautika [5].

Penelitian ini membahas tentang akurasi perhitungan penentuan posisi berdasarkan hasil perhitungan tinggi hitung matahari yang didapat anatara metode perhitungan Sight Reduction Table (SRT) dengan Daftar Ilmu Pelayaran (DIP).

Penelitian sebelumnya yang pernah dilakukan terkait dengan perhitungan tinggi benda angkasa dalam penentuan posisi dilakukan oleh Ari Sriantini pada tahun 2011 dengan hasil yang didapat bahwa dalam perhitungan dan penentuan posisi astronomi, merupakan penentuan posisi sejati kapal dengan menggunakan benda-benda angkasa sebagai alat bantu untuk bernavigasi. Pengamatan terhadap benda angkasa tersebut bisa dilakukan pada 2 benda angkasa atau lebih dalam waktu yang bersamaan atau hampir bersamaan, dan bisa juga terhadap satu benda angkasa, namun waktu pengamatannya berbeda. Dan perhitungan dan penentuan koordinat posisi kapal dapat dilakukan dengan cara konstruksi maupun perhitungan [6].

\section{Materi dan Metode}

Dalam penelitian ini mencantumkan beberapa materi yang dianggap penting guna memudahkan pembaca dalam memahami penelitian ini. Adapun beberapa teori tersebut sebagai berikut:

1. Sight Reduction Table (SRT) merupakan suatu terbitan berisikan tabel-tabel yang diperuntukan untuk para marinir/pelaut sebagai alat bantu navigasi benda angkasa (celestial navigation). Tujuan utama tabel ini adalah untuk memfasilitasi praktik navigasi di laut. Tujuan sekunder adalah untuk memberikan, dalam batasan ketelitian dan interval tabel, tabel resolusi segitiga berbentuk bola yang diketahui dua sisi dan sudut yang disertakan perlu untuk menemukan nilai sisi ketiga dan sudut yang berdekatan. Tabel telah dirancang terutama untuk digunakan dengan metode intercept dari pengamatan (Sight Reduction), menggunakan posisi yang diasumsikan atau dipilih sehingga interpolasi pada lintang dan sudut jam lokal tidak diperlukan. Untuk memasukkan argumen derajat integral lintang, deklinasi, dan lokal sudut jam, ketinggian dan perbedaannya ditabulasikan 
hingga sepersepuluh menit terdekat, sudut azimuth hingga sepersepuluh derajat terdekat.

2. Menurut Sugeng (2010) kepala Pusat Hidrografi dan Oseanografi Angkatan Laut (PUSHIDROSAL), buku Daftar Ilmu Pelayaran bermanfaat untuk melakukan perhitungan ketinggian, haluan dan jarak, pengamatan benda-benda angkasa serta perhitungan lainnya. Daftar Ilmu Pelayaran memuat keperluan perhitungan ramalan pasang surut dan arus pasang surut dengan metode analisa harmonis. Perhitungan dekat derajah (circum merdian) dapat dilakukan dalam batas lintang yang sesuai dengan melakukan pengamatan pada waktu senja pada arah $\mathrm{U}, \mathrm{T}, \mathrm{S}$ dan $\mathrm{B}$ untuk penentuan posisi astronomi. Buku Daftar Ilmu Pelayaran mengakomodasi perhitungan menurut Marcoq St. Hilaure, dimana logaritma perbandingan garis sudut-sudut antara 0 dan 90 dihitung setiap setengah menit busur (daftar - VIII) [5].

3. Menurut Arso Martopo (1992) Azimuth benda angkasa adalah sebagian busur cakrawala, dihitung dari titik utara atau selatan sesuai dengan lintang penilik, ke arah barat atau timur sampai ke lingkaran tegak yang melalui benda angkasa, diukur dari $0^{0}$ sampai $180^{\circ}$. Sebuah segitiga bola diangkasa dengan Zenith, Kutub angkasa dan benda angkasa sebagai titik sudutnya serta sisisisinya $90^{\circ}-\mathrm{lt}, 90^{\circ}-\mathrm{z}$ dan $90^{\circ}-\mathrm{ti}$. Sedangkan sudut pada segitiga paralak tersebut adalah azimuth, sudut jam dan sudut paralak [6].

4. Menurut Mardiansaf (2017) sextant merupakan sebuah alat navigasi yang digunakan untuk menentukan posisi kapal, dengan cara mengukur ketinggian benda langit di atas cakrawala. Fungsi utama dari sextant adalah untuk menentukan sudut antara benda astronomi dan cakrawala, yang disebut juga penampakan (atau menembak) objek benda angkasa. Penggunaan umum dari sextant adalah untuk mengukur tinggi matahari pada saat cuaca cerah di siang hari, dan bintang Polaris pada saat malam hari yang cerah (di belahan Bumi utara) untuk mendapatkan lintang posisi kapal. Sextant dapat juga digunakan untuk mengukur jarak antara Bulan dan objek benda angkasa lainnya (seperti bintang atau planet) guna menentukan Greenwich Mean Time (GMT) dan bujur. [7].

Desain penelitian ini menggunakan metode deskriptif komparatif berbasis studi lapangan (field research) dengan pendekatan kuantitatif Penelitian kuantitatif adalah aktivitas peneliti untuk memperoleh fakta dengan menggunakan data numerik sebagai dasar pertama untuk menganalisis apa yang diketahui dan dipahami.

Tempat penelitian dilaksanakan di tiga lokasi yang berbeda yaitu: Lokasi I berada di Pesesir Pantai Marina Semarang, Jawa Tengah, Lokasi II berada di Pelabuhan Kendal Jawa Tengah, dan Lokasi III berada di Pesisir Pantai Jepara Jawa Tengah. Pada tiga lokasi yang berbeda tersebut sasaran objek penelitian ini adalah mengukur tinggi matahari yang kemudian disebut tinggi ukur matahari (Tu $\odot$ ). Pengukuran dilakukan menggunakan alat sextant dengan memproyeksikan matahari ke cakrawala (horizon).

Objek penelitian pada penelitian ini adalah tinggi matahari yang kemudian disebut tinggi ukur matahari (Tu $\odot$ ). Observasi benda angkasa dilakukan dengan memakai sextant serta mencatat pada penunjuk pengukur waktu (chronometer).

Penelitian ini menggunakan data yang bersifat kuantitatif yang berkaitan dengan objek yang diteliti. Berdasarkan sumbernya, data yang diperoleh dapat dibedakan menjadi 2 yaitu; 1 ). Data primer dalam penelitian ini menggunakan data yang didapat secara langsung dari sumbernya dengan cara pengamatan yang berhubungan dengan materi dibahas Data dikumpulkan sendiri oleh peneliti langsung dari sumber pertama atau tempat objek penelitian dilakukan dan 2). Data sekunder dalam penelitian ini literatur, artikel, jurnal, serta situs internet yang telah teruji validitasnya. data sekunder diperoleh dari pengumpulan data dengan cara mempelajari dan menelaah dokumen yang berkaitan dengan akurasi perhitungan nilai Tinggi Matahari antara perhitungan Daftar Ilmu Pelayan dan Sight Reduction Table.

Teknik pengumpulan data yang digunakan dalam penelitian ini yaitu: 1). Teknik Observasi, 2). Teknik Dokumentasi dan 3). Teknik Studi Pustaka.

Teknik analisis data yang digunakan dalam penelitian ini adalah analisis Komparatif. Pada 
model analisis ini ada 5 komponen analisis yang perlu diperhatikan, yaitu Penentuan masalah penelitian, Penentuan kelompok yang memiliki karakteristik yang ingin diteliti, Pemilihan kelompok pembanding, Pengumpulan data, dan Analisis data

\section{Hasil dan Pembahasan}

Penentuan tinggi benda-benda angkasa merupakan salah satu langkah awal dalam perhitungan penentuan posisi kapal secara astronomi. Pengambilan tinggi benda-benda angkasa tersebut merupakan alat bantu dalam bernavigasi [8]. Benda-benda angkasa yang dimaksud antara lain adalah matahari, bulan, bintang dan planet-planet lainnya. Hal ini juga sejalan dengan pendapat yang menyatakan bahwa dasar dari semua metode yang direkomendasikan untuk memperoleh posisi dengan menggunakan benda langit adalah ketinggian yang diketahui dari benda angkasa yang sedang diamati [9]. Untuk itu perlu adanya sextant atau perangkat lain yang dapat mengukur ketinggian benda tersebut.

Tinggi ukur hasil pengamatan benda-benda angkasa yang dalam hal ini peneliti mengamati tinggi Matahari adalah dengan menggunakan sextant. Untuk memperjelas, peneliti menjabarkan tata cara penggunaan sextant untuk mengukur tinggi ukur matahari yang dilakukan dengan cara sebagai berikut:

1. Bidik Benda Angkasa (matahari) secara vertikal;

2. Tarik lengan indeks hingga memproyeksikan matahari ke garis cakrawala (bayangan matahari persis berada diatas garis cakrawala);

3. Sekali-kali goyangkan sextant ke kanan dan ke kiri untuk menguji apakah proyeksi bayangan matahari tepat berada di garis cakrawala;

4. Setelah itu perhalus dengan menyesuaikan/ memutar indeks drum atau nonius sextant untuk memperoleh nilai menit dan detik;

5. Jika matahari terlelu terang dapat menggunakan kaca berwarna untuk mengurangi jumlah pantulan cahaya;

6. Selanjutnya amati lengan indeks dan indeks drum untuk mendapatkan nilai tinggi matahari ( Tu $\odot$ ) atau disebut dengan altitude matahari.
Dalam hal pengamatan dan praktek pengukuran yang dilakukan di lapangan tidak luput akan kesalahan (human error) karena instrument yang digunakan merupakan instrumen optik dimana dalam penggunaannya dibutuhkan kecermatan atau ketelitian yang tinggi untuk mendapatkan hasil yang akurat. Selain adanya human error perlu diperhatikan faktor-faktor lainnya yang dapat mempengaruhi hasil pengamatan tinggi matahari. Adapun faktor-faktor tersebut antara lain:

1. Standar waktu

2. Keadaan cuaca

3. Tempat observasi dan jangkauan terhadap cahaya

4. Posisi badan dan keseimbangan lengan saat memegang sextant

Pada pengamatan/observasi tahap pertama dilaksanakan di pesisir pantai Marina pada tanggal 20 September 2020 dengan titik koordinat koordinat 6 $6^{\circ} 56^{\prime} 46^{\prime \prime}$ LS dan $110^{\circ} 23^{\prime} 33^{\prime \prime}$ BT. Berikut hasil observasi yang didapat sebagaimana tabel 1 di bawah ini:

Tabel. 1 Hasil Observasi Tinggi Ukur Matahari di Pantai Marina Semarang

\begin{tabular}{|l|ccc|}
\hline Observasi & Observasi I & $\begin{array}{c}\text { Observasi } \\
\text { II }\end{array}$ & $\begin{array}{c}\text { Observasi } \\
\text { III }\end{array}$ \\
\hline Waktu & $09: 20: 21$ & $09: 50: 38$ & $10: 20: 21$ \\
Hasil & $56^{0} 17^{\prime} 36 "$ & $64^{0} 31^{\prime} 42^{\prime}$ & $71^{0} 333^{\prime} 12 ”$ \\
TMP & Tinggi Mata Penilik $=2.2$ & meter di atas \\
& \multicolumn{2}{|l}{ permukaan air } \\
\hline
\end{tabular}

observasi tahap kedua dilaksanakan di pelabuhan Kendal pada tanggal 30 September 2020 dengan titik koordinat 60 56'06' LS dan 1100 17'16" BT. Sama seperti sebelumnya peneliti menggunakan 2 buah sextant untuk menguji validitas dan sebagai pembanding keakuratan hasil observasi pengamat. Berikut hasil observasi yang didapat sebagaimana tabel 2 di bawah ini

Tabel. 2 Hasil Observasi Tinggi Ukur Matahari di Pelabuhan Kendal

\begin{tabular}{|c|c|c|c|}
\hline Observasi & Observasi I & $\begin{array}{c}\text { Observasi } \\
\text { II }\end{array}$ & $\begin{array}{c}\text { Observasi } \\
\text { III }\end{array}$ \\
\hline Waktu & 09: 15:03 & $09: 45: 16$ & $10: 15: 04$ \\
\hline Hasil & $56^{0} 30^{\prime} 12^{\prime \prime}$ & $63^{0} 57^{\prime} 42^{\prime \prime}$ & $71^{0} 39^{\prime} 42^{\prime \prime}$ \\
\hline TMP & \multicolumn{3}{|c|}{$\begin{array}{l}\text { Tinggi Mata Penilik }=3.5 \text { meter di atas } \\
\text { permukaan air }\end{array}$} \\
\hline
\end{tabular}


Selanjutnya observasi tahap ketiga dilaksakan di pesisir pantai Jepara pada tanggal 1 Oktober 2020 dengan titik koordinat $6^{\circ} 56^{\prime} 06^{\prime \prime}$ LS dan $110^{\circ} 17^{\prime} 16^{\prime \prime}$ BT. Kegiatan observasi ini dilaksakan pada sore hari dimana matahari telah melewati merpass. Berikut hasil observasi yang didapat sebagaimana tabel 3 di bawah ini:

Tabel. 3 Hasil Observasi Tinggi Ukur Matahari di Jepara

\begin{tabular}{|l|lcc|}
\hline Observasi & $\begin{array}{l}\text { Observasi } \\
\text { I }\end{array}$ & Observasi & Observasi \\
& II & III \\
\hline Waktu & $14: 30: 09$ & $15: 00: 03$ & $15: 30: 18$ \\
Hasil & $44^{0} 19^{\prime} 48^{\prime \prime}$ & $36^{0} 54^{\prime} 24^{\prime \prime}$ & $29^{0} 22^{\prime} 48^{\prime \prime}$ \\
TMP & Tinggi Mata Penilik $=1.8$ meter di atas \\
& permukaan air \\
\hline
\end{tabular}

Dalam observasi benda angkasa menggunakan sextant, nilai yang ditunjukkan bukan merupakan nilai tinggi sejati melainkan adalah nilai tinggi ukur maya (TUm). Untuk mendapatkan nilai tinggi ukur sejati (TUs) perlu dilakukannya koreksi-koreksi dengan bantuan data Almanak Nautika. Adapun koreksi nilai tinggi ukur tersebut dapat dilakukan dengan menggunakan rumus sebagai berikut:

$\mathrm{TS}=\mathrm{TU}-\mathrm{KI}-\mathrm{PTLM}-\mathrm{LSA}+\mathrm{Par} \pm 1 / 2 \mathrm{GT}$

Keterangan:

TS : Tinggi Sejati Matahari

TU : Tinggi Ukur Matahari Maya

KI : Koreksi Indeks Sextant

PTLM : Penundukan Tepi Langit Maya

(Kerendahan Cakrawala) LSA : $\underset{\text { (Refraksi/Pembiasan) }}{\text { Lengkung Astronomi }}$

1/2 GT : Setengah Garis Tengah (Jari-jari)

Dalam melakukan koreksi sextant dapat dilakukan dengan memperhatikan cara sebagai berikut:

1. Nilai PTLM dapat dicari pada Daftar Ilmu Pelayaran (DIP) Daftar Tabel XVIII pada kolom tepi langit bebas dengan argumentasi tinggi mata penilik atau dicari pada buku Almanak Nautika (DIP Correction table A2). Koreksi PTLM bernilai negatif (-)

2. Koreksi Indeks berhubungan alhidade yang ada di sextant, dimana koreksi ini disebabkan oleh pemuaian bahan sextant. Nilai kesalahan indeks dapat ditentukan dengan cara melihat cakrawala/ horizon apakah masih satu garis atau tidak, bila tidak segaris maka dapat diatur dengan nonius sampai benar-benar segaris setelahnya dibaca nilai noniusnya apakah positif atau negatif.

3. LSA atau refraksi astronomi dapat dicari dengan Daftar Ilmu Pelayaran (DIP) Daftar $\mathrm{XX}$ dengan asumsi temperatur udara $>10^{\circ} \mathrm{C}$ dan nilai koreksinya negatif.

4. Paralaks merupakan perbedaan arah dimana benda yang sama dilihat dari dua titik berbeda yaitu titik pusat Bumi dan titik pusat mata pengamat. Hal ini dapat diketahui dengan rumus $\mathrm{P}=\mathrm{HP} \cos \mathrm{t}$. Untuk Koreksi Parallax matahari adalah 00, 0024, maka sesuai dengan petunjuk buku almanak nautika koreksi ini dapat diabaikan.

5. Koreksi $1 / 2$ GT Matahari dapat dilihat di Almanak Nautika di urutan paling bawah GHA matahari dengan symbol SD (Semi Diameter) dan disesuaikan dengan bulan dan tanggal pengambilan.

Berdasarkan cara-cara diatas maka untuk koreksi sextant didapat hasil perhitungan koreksi dan tinggi sejati matahari sebagai berikut:

Tabel 4. Data Tinggi Sejati Matahari

\begin{tabular}{|c|c|c|c|}
\hline Lokasi & $\begin{array}{c}\text { Observasi I } \\
\text { (Pukul) }\end{array}$ & $\begin{array}{c}\text { Observasi II } \\
\text { (Pukul) }\end{array}$ & $\begin{array}{l}\text { Observasi III } \\
\text { (Pukul) }\end{array}$ \\
\hline $\begin{array}{c}\text { Pantai } \\
\text { Marina } \\
\text { 20 Sept } 2020\end{array}$ & $\begin{array}{l}\mathbf{5 6}^{\mathbf{0}} \mathbf{1 9} \mathbf{9}^{\prime} \mathbf{2 3} ” \\
(09: 20: 21)\end{array}$ & $\begin{array}{c}\text { 630 33' 29"' }^{\text {(09:50:38) }}\end{array}$ & $\begin{array}{c}\mathbf{7 0}^{0} \text { 34' 58" } \\
(10: 20: 21)\end{array}$ \\
\hline $\begin{array}{c}\text { Pelabuhan } \\
\text { Kendal } \\
30 \text { Sept } 2020\end{array}$ & $\begin{array}{l}\mathbf{5 6}^{\mathbf{0}} \text { 31' 02" } \\
(09: 15: 03)\end{array}$ & $\begin{array}{c}\mathbf{6 3}^{\mathbf{0}} \mathbf{5 8} \mathbf{\prime}^{\prime} \mathbf{3 2} " \\
(09: 45: 16)\end{array}$ & $\begin{array}{l}\mathbf{7 1}^{\mathbf{0}} \mathbf{4 0} \mathbf{\prime}^{\prime} \mathbf{3 2}{ }^{\prime} \\
(10: 15: 04)\end{array}$ \\
\hline $\begin{array}{c}\text { Pantai } \\
\text { Jepara } \\
1 \text { Oktober } \\
2020\end{array}$ & $\begin{array}{l}\text { 44 }^{\mathbf{0}} \text { 21' 07”' } \\
(14: 30: 09)\end{array}$ & $\begin{array}{c}\mathbf{3 6}^{\mathbf{0}} \mathbf{5 5} \mathbf{2}^{\prime} \mathbf{4 3} \\
(15: 00: 03)\end{array}$ & $\begin{array}{c}\mathbf{2 9}^{\mathbf{0}} \mathbf{2 4} \mathbf{9}^{\prime} \mathbf{0 7} \\
(15: 30: 18)\end{array}$ \\
\hline
\end{tabular}

Tinggi Hitung Matahari dapat dilakukan dengan 2 metode perhitungan, yaitu dengan perhitungan menggunakan tabel Daftar Ilmu Pelayaran dan Sight Reduction Table (SRT). Tujuan dilakukan perhitungan ini adalah untuk menentukan selisih tinggi benda angkasa (delta altitude) yang didapat dari selisih antara Tinggi Ukur Sejati (TUs) dengan Tinggi Hitung (TH). Dalam pelayaran selisih ini juga dikenal dengan intercept (p) untuk menentukan posisi arah garis tinggi (agt) apakah positif atau negatif dari posisi 
duga kapal. Selanjutnya dengan diketahui intercept dan azimuth pelaut mengerjakannya dalam plotting sheet atau bestek untuk menentukan posisi kapal dengan perpotongan 3 buah arah garis tinggi (agt).

Pada penelitian ini peneliti mencoba untuk mengukur tingkat akurasi dari masing-masing metode perhitungan baik dengan Daftar Ilmu Pelayaran dan Sight Reduction Table (SRT) dengan membandingkan perhitungan tersebut terhadap tinggi sejati matahari (Ts). Tinggi sejati (Ts) matahari ini diambil dengan posisi tetap tidak bergerak dan lintang bujur dicatat dengan GPS. Sehingga peneliti mengasumsikan tinggi sejati tersebut sebagai Posisi Sejati.

1. Perhitungan Tinggi Hitung (Th) Metode Daftar Ilmu Pelayaran (DIP). Perhitungan tinggi hitung ini didapat dengan menggunakan rumus: $\operatorname{Sin} \mathrm{Th}=\mathrm{Cos}(\mathrm{Lt} \pm \mathrm{Z})$

- Cos Lt. Cos Z SinvP. Dengan rumus ini peneliti melakukan perhitungan dan cara penyelesaian sebagai berikut:

Sampel Perhitungan Tinggi Hitung Pada Tanggal 20 September di Pantai Marina dengan data asumsi perhitungan sebagai berikut:

$\begin{array}{ll}\text { Latitude } & : 06^{0} 56^{\prime} 48^{\prime \prime} \\ \text { Local Time } & : 09: 20: 21 \\ \text { Longitude } & : 110^{\circ} 23^{\prime} 36^{\prime \prime} \\ \text { Tu } & : 56^{0} 17^{\prime} 36^{\prime \prime}\end{array}$

\begin{tabular}{|c|c|c|c|c|}
\hline GMT & $=$ & 02: 20: 21 & & \\
\hline GHA & $=$ & $211^{0} 38^{\prime} 48^{\prime \prime}$ & & $\begin{array}{l}\text { Tabel Almanac } \\
\text { Nautika }\end{array}$ \\
\hline Incr. GHA & $=$ & $05^{0} 05^{\prime} 18^{\prime \prime}+$ & + & $\begin{array}{ll}\text { Tabel Incr } \\
\text { Almanac } \\
\text { Nautika }\end{array}$ \\
\hline GHA $\odot$ & $=$ & $216^{0} 44^{\prime} 06^{\prime \prime}$ & & \\
\hline Longitude & $=$ & $110^{0} 23{ }^{\prime} 36^{\prime \prime}$ & + & \\
\hline LHA $\odot$ & $=$ & $327^{0} 0^{\prime} 48^{\prime \prime}$ & & \\
\hline $\mathrm{P} / \mathrm{HA}$ & $=$ & $32^{0} 52^{\prime} 12^{\prime \prime}$ & & 360- LHA \\
\hline Declination & $=$ & $\begin{array}{l}00^{0} \quad 57^{\prime} \\
\mathrm{N}\end{array}$ & $54 "$ & $\begin{array}{c}\text { Tabel Almanac } \\
\text { Nautica }\end{array}$ \\
\hline Dec. Corr & $=$ & $00^{0} 00^{\prime} 49^{\prime \prime}$ & + & $\begin{array}{l}\text { Tabel Incr } \\
\text { Almanac } \\
\text { Nautika }\end{array}$ \\
\hline
\end{tabular}

\begin{tabular}{|c|c|c|c|c|}
\hline A & $=$ & $0.19 \mathrm{~S}$ & & DIP Tabel X \\
\hline B & $=$ & $0.03 \mathrm{~N}$ & - & DIP Tabel XI \\
\hline $\mathrm{C}$ & $=$ & 0.16 & & DIP Tabel XII \\
\hline $\mathrm{Tb}$ & $=$ & $99^{0}$ & & \\
\hline Azimuth & $=$ & $\mathrm{S} 81^{0} \mathrm{~T}$ & & \\
\hline $\begin{array}{l}\text { Cos } \quad(\mathrm{Lt} \pm \\
\mathrm{Z})\end{array}$ & $=$ & 0.990456415 & & Disebut Term I \\
\hline Cos Lt & $=$ & 0.99266165 & & Disebut Term \\
\hline Cos. Z & $=$ & 0.999854741 & & \\
\hline $\operatorname{Cos} \mathrm{P}$ & $=$ & 0.839934980 & & $\operatorname{SinvP}=1-$ \\
\hline SinvP & $=$ & 0.16006502 & & Cos $\mathrm{P}$ \\
\hline Sin Th & $=$ & 0.831589089 & & $\begin{array}{c}\text { Term I - Term } \\
\text { II }\end{array}$ \\
\hline Th & $=$ & 56.27 & & \\
\hline Th $\odot$ & & $56^{0} 15,36^{\prime \prime}$ & & \\
\hline
\end{tabular}

Perhitungan di atas menggunakan tabel almanac nautika tahun 2020 dan Daftar Ilmu Pelayaran (DIP) serta dihitung dengan bantuan kalkulator untuk mempermudah.

2. Perhitungan Tinggi Hitung (Th) Metode Sight Reduction Table (SRT) ini didapat dengan menggunakan asumsi-asumsi sesuai dengan petunjuk pengerjaan yang dijelaskan pada buku Sight Reducition Table (SRT). Hasil tinggi hitung matahari yang diperoleh berbeda. Dimana selisih yang ada tidak terlalu signifikan yaitu di bawah 10 (sepuluh) menit. Selain itu kedua metode perhitungan di atas sekaligus dapat menentukan azimuth. Berdasarkan hasil perhitungan tersebut peneliti memberikan data hasil perhitungan kedua metode sebagaimana tabel di bawah ini:

Tabel 5. Data Hasil Perhitungan Tinggi Sejati Matahari dengN DIP dan SRT

\begin{tabular}{|c|c|c|c|c|c|}
\hline No & Lokasi & Obsrv & $\begin{array}{c}\text { Th } \Theta \\
\text { DIP }\end{array}$ & $\begin{array}{l}\text { Th } \odot \\
\text { SRT }\end{array}$ & Ts $\odot$ \\
\hline \multirow[t]{3}{*}{1} & \multirow{3}{*}{$\begin{array}{l}\text { Pantai } \\
\text { Marina }\end{array}$} & I & $56^{0} 15^{\prime} 36^{\prime \prime}$ & $56^{0} 13^{\prime} 00^{\prime \prime}$ & $56^{0} 19^{\prime} 23^{\prime \prime}$ \\
\hline & & II & $63^{0} 30^{\prime} 00^{\prime \prime}$ & $63^{0} 27^{\prime} 00^{\prime \prime}$ & $63^{0} 33^{\prime} 29^{\prime \prime}$ \\
\hline & & III & $70^{0} 30^{\prime} 36^{\prime \prime}$ & $70^{0} 29^{\prime} 00^{\prime \prime}$ & $70^{0} 34^{\prime} 58^{\prime \prime}$ \\
\hline \multirow[t]{3}{*}{2} & \multirow{3}{*}{$\begin{array}{l}\text { Pelabuhan } \\
\text { Kendal }\end{array}$} & I & $56^{0} 27^{\prime} 36^{\prime \prime}$ & $56^{0} 24^{\prime} 00^{\prime \prime}$ & $56^{0} 31^{\prime} 02^{\prime \prime}$ \\
\hline & & II & $63^{0} 55^{\prime} 12^{\prime \prime}$ & $63^{0} 52^{\prime} 00^{\prime \prime}$ & $63^{0} 58^{\prime} 32^{\prime \prime}$ \\
\hline & & III & $71^{0} 37^{\prime} 48^{\prime \prime}$ & $71^{0} 34^{\prime} 00^{\prime \prime}$ & $71^{0} 40^{\prime} 32^{\prime \prime}$ \\
\hline \multirow[t]{3}{*}{3} & \multirow{3}{*}{$\begin{array}{l}\text { Pantai } \\
\text { Jepara }\end{array}$} & I & $44^{0} 18^{\prime} 00^{\prime \prime}$ & $44^{0} 16^{\prime} 00^{\prime \prime}$ & $44^{0} 21^{\prime} 07^{\prime \prime}$ \\
\hline & & II & $36^{0} 52^{\prime} 12^{\prime \prime}$ & $36^{0} 49^{\prime} 00^{\prime \prime}$ & $36^{0} 55^{\prime} 43^{\prime \prime}$ \\
\hline & & III & $29^{0} 21^{\prime} 36^{\prime \prime}$ & $29^{0} 19^{\prime} 00^{\prime \prime}$ & $29^{0} 24^{\prime} 07^{\prime \prime}$ \\
\hline
\end{tabular}


Peneliti menggambarkan ilustrasi dengan menampilkan grafik untuk membuktikan tingkat akurasi hasil perhitungan antara DIP dan SRT sebagaimana tercantum pada grafik yang disajikan di bawah ini:

Gambar 1. Perbandingan Perhitungan Th $\odot$ dengan Ts $\odot$

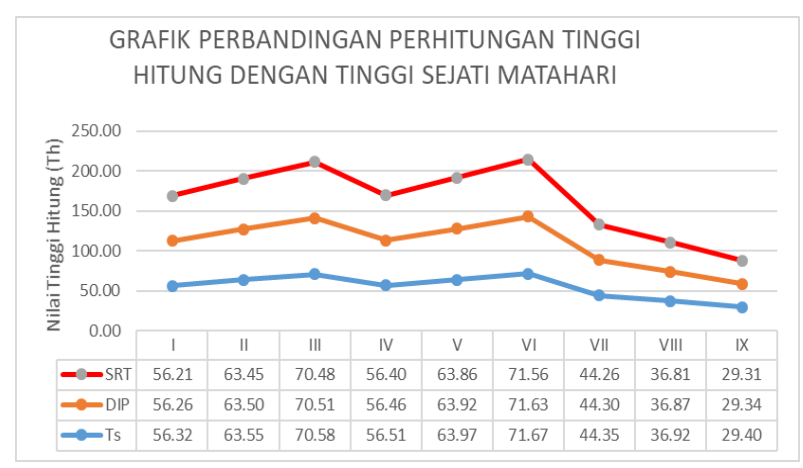

Keterangan:

1. I-III adalah hasil perhitungan dan observasi matahari di Pantai Marina;

2. IV-VI adalah hasil perhitungan dan observasi matahari di Pelabuhan Kendal;

3. VII-IX adalah hasil perhitungan dan observasi matahari di Pantai Jepara.

Jika diasumsikan Ts adalah posisi sejati (garis berwarna biru), maka dari grafik di atas didapat bahwa hasil perhitungan metode Daftar Ilmu Pelayaran (DIP) yang ditunjukan oleh garis berwarna oranye lebih mendekati Ts (garis biru) diandingkan dengan hasil perhitungan SRT yang ditunjukan garis merah yang mana lebih jauh dari Ts (garis biru). Dari penjelasan tersebut dapat diektahui bahwa perhitungan DIP lebih akurat dibandingkan SRT.

Untuk menentukan posisi kapal dalam pelayaran, para mualim atau Nakhoda biasanya melakukan penggambaran di peta atau menggunakan plotting sheet (bestek), sehingga untuk penentuan posisi kapal dengan bantuan observasi benda angkasa, perlu ditentukan selisih tinggi hitung dengan tinggi sejati matahari yang biasa disebut intercept (p) atau delta altitude dengan rumus $(\mathrm{p}=\mathrm{Ts} \odot-$ Th $\odot)$ dimana tinggi hitung (th) matahari didapat berdasarkan perhitungan metode DIP maupun SRT. Intercept ini akan diigunakan untuk menentukan jarak arah garis tinggi (agt) dari posisi duga kapal. Arah garis tinggi tersebut ditarik dengan sudut 900 (sudut siku-siku) dengan jarak sesuai dengan skala intercept dari posisi duga kapal. Metode ini dikenal dengan penentuan posisi secara perpotongan dua atau lebih arah garis tinggi (agt) yang kemudian didapat posisi kapal. Perhitungan intercept sebagaimana pada tabel di bawah ini:

Tabel 6. Data perhitungan intercept (p)

\begin{tabular}{|c|c|c|c|c|}
\hline No & Observasi & $\begin{array}{c}\text { Ts } \odot \\
\text { (A) }\end{array}$ & $\begin{array}{c}\mathbf{p}_{1} \\
(\mathbf{A}-\mathbf{B})\end{array}$ & $\begin{array}{c}\mathbf{p}_{2} \\
(\mathbf{A}-\mathrm{C})\end{array}$ \\
\hline \multirow[t]{3}{*}{1} & \multirow{3}{*}{$\begin{array}{l}\text { Pantai } \\
\text { Marina }\end{array}$} & $56^{0} 19^{\prime} 23^{\prime \prime}$ & $+\left(3^{\prime} 47^{\prime \prime}\right)$ & $+\left(6^{\prime} 23^{\prime \prime}\right)$ \\
\hline & & $63^{0} 33^{\prime} 29^{\prime \prime}$ & + (3'29') & $+\left(6^{\prime} 29^{\prime \prime}\right)$ \\
\hline & & $70^{\circ} 34^{\prime} 58^{\prime \prime}$ & $+\left(4 ' 22^{\prime \prime}\right)$ & $+\left(5^{\prime} 58^{\prime \prime}\right)$ \\
\hline \multirow[t]{3}{*}{2} & \multirow{3}{*}{$\begin{array}{l}\text { Pelabuhan } \\
\text { Kendal }\end{array}$} & $56^{0} 31^{\prime} 02^{\prime \prime}$ & $+\left(3{ }^{\prime} 26^{\prime \prime}\right)$ & $+\left(7^{\prime} 02^{\prime \prime}\right)$ \\
\hline & & $63^{0} 58^{\prime} 32^{\prime \prime}$ & $+\left(3^{\prime} 20^{\prime \prime}\right)$ & $+\left(6^{\prime} 32^{\prime \prime}\right)$ \\
\hline & & $71^{0} 40^{\prime} 32^{\prime \prime}$ & $+\left(2^{\prime} 44^{\prime \prime}\right)$ & $+\left(6{ }^{\prime} 32^{\prime \prime}\right)$ \\
\hline \multirow[t]{3}{*}{3} & \multirow{3}{*}{$\begin{array}{l}\text { Pantai } \\
\text { Jepara }\end{array}$} & $44^{0} 21^{\prime} 07^{\prime \prime}$ & $+\left(3^{\prime} 07^{\prime \prime}\right)$ & $+\left(5^{\prime} 07^{\prime \prime}\right)$ \\
\hline & & $36^{0} 55^{\prime} 43^{\prime \prime}$ & $+\left(3{ }^{\prime} 31^{\prime \prime}\right)$ & $+\left(6^{\prime} 43^{\prime \prime}\right)$ \\
\hline & & $29^{0} 24^{\prime} 07^{\prime \prime}$ & $+\left(2{ }^{\prime} 31^{\prime \prime}\right)$ & $+\left(5^{\prime} 07^{\prime \prime}\right)$ \\
\hline
\end{tabular}

Untuk membuktikan tingkat akurasi perhitungan tinggi hitung menggunakan intercept. Aplikasi tinggi hitung matahari terhadap posisi kapal dapat digambarkan melalui bestek atau gambar. Data di atas jika digambarkan ke dalam bestek penentuan posisi kapal, maka akan dapat diketahui bahwa arah garis tinggi 1 (agt 1) lebih dekat perpotongannya dengan TS yang dalam hal ini diasumsikan sebagai posisi sejati (fix) sedangkan arah garis tinggi 2 (agt 2) perpotongannya lebih jauh dari posisi sejati. Sehingga dalam pembuktian bestek ini dapat diketahui bahwa akurasi perhitungan metode DIP lebih akurat dibandingkan dengan metode perhitungan SRT.

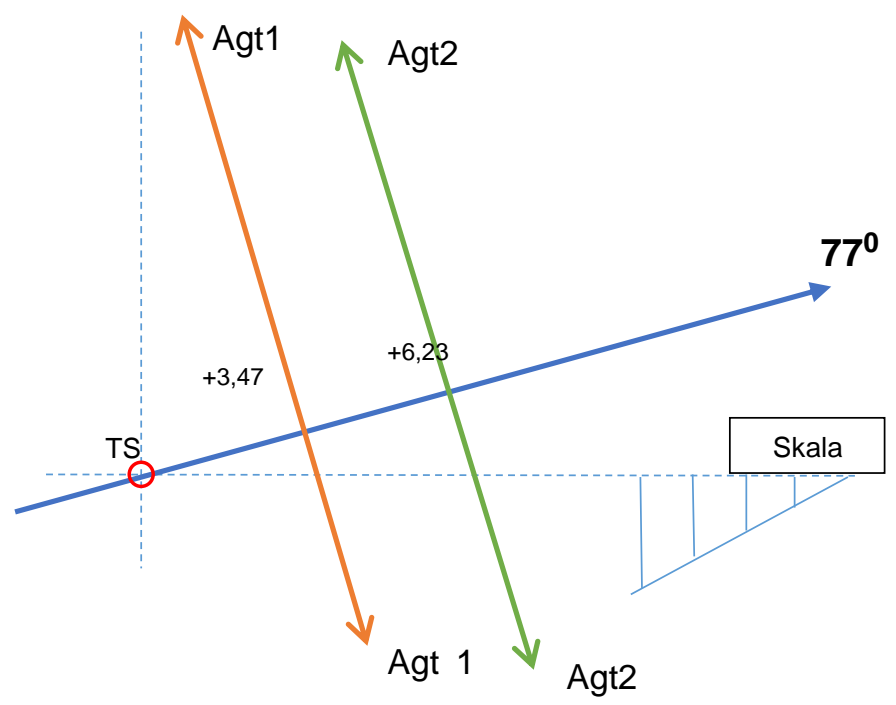

Gambar 2. Bestek penentuan posisi dengan intercept (p)

Keterangan:

TS : Posisi Sejati

Agt 1 : arah garis tinggi berdasarkan intercept 
perhitungan DIP

Agt 2 : Arah garis tinggi berdasarkan intercept perhitungan SRT

\section{Kesimpulan}

Berdasarkan hasil analisis dan pembahasan yang telah diuraikan dalam penelitian ini, maka pada bagian akhir penelitian ini peneliti menyimpulkan bahwa metode perhitungan tinggi hitung matahari menggunakan metode perhitungan Daftar Ilmu Pelayaran (DIP) lebih akurat dibandingkan dengan metode perhitungan Sight Reduction Table (SRT) dengan selisih perhitungan Th DIP dengan Ts sebesar \pm 3 ' sedangkan selisih perhitungan Th SRT dengan Ts sebesar $\pm 6,5^{\prime}$

\section{Ucapan terima kasih}

Penulis mengucapkan terima kasih atas dukungan segala pihak yang terkait dalam penelitian ini khususnya Politeknik Ilmu Pelayaran Semarang.

\section{Daftar Pustaka}

[1] Swaszek, P. F., Hartnett, R. J., \& Seals, K. C. (2020). Celestial NavigationCorrecting the Folklore. 2020 IEEE/ION Position, Location and Navigation Symposium (PLANS), 949-959. https://doi.org/10.1109/PLANS46316.2020. 9109928

[2] Nguyen, V. S. (2020). A Theoretical Approach of Astronomical Ship Positioning Using a Single Celestial Body and Secant Technique. International Journal Of Fuzzy Logic And Intelligent Systems, 20(1), 1-7. https://doi.org/10.5391/IJFIS.2020.20.1.1

[3] Nguyen, V. S. (2019). A Novel Approach To Determine The Ship Position With An Azimuth Of Celestial Body And Factors Of Ship. International Journal of Civil Engineering and Technology (IJCIET) Scopus Indexed .

[4] Lušić, Z. (2018). Astronomical position without observed altitude of the celestial body. Journal of Navigation, 71(2), 454466.https://doi.org/10.1017/S03734633170 0073X

[5] Dinas Hidro Oceanografi TNI Angkatan Laut. (2016). Daftar Ilmu Pelayaran. DISHIDROS. Jakarta
[6] Arso Martopo (1992). Ilmu Pelayaran Astronomi. Balai Pendidikan dan Latihan Pelayaran : Semarang, Indonesia

[7] Murdiansaf. (2017). Rain. Ilmu Pelayaran, Jakarta: EDC

[8] Sriantini, A. (2011). Perhitungan Posisi Sejati Kapal Dengan Pengamatan Terhadap Benda-Benda Angkasa. 7.

[9] Lušić, Z. (2018). Astronomical position without observed altitude of the celestial body. Journal of Navigation, 71(2), 454466.https://doi.org/10.1017/S03734633170 0073X 